\title{
Mistä asiantuntijuUs MUODOSTUU? ONGELMAPELAAJIEN KOHTAAMINEN SOSIAALIALALLA
}

Johanna Järvinen-Tassopoulos: dosentti, erikoistutkija, Terveyden ja byvinvoinnin laitos

Minna Kesänen: YTL, erikoissuunnittelija, Terveyden ja byvinvoinnin laitos

johanna.jarvinen-tassopoulos.thl.fi; minna.kesanen@thl.fi

Janus vol. 28 (2) 2020, 150-167

Tiivistelmä

\section{$\int$ d}

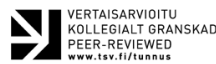

Rahapelaamisen mahdollisuuksien kasvaessa sosiaalialalla toimivat työntekijät tulevat todennäköisesti kohtaamaan rahapeliongelmista kärsiviä asiakkaita. Työntekijöiden asiantuntijuutta tarvitaan asiakkaan ongelman tunnistamisessa, hänen auttamisessaan ja ohjaamisessaan oikeanlaisten palvelujen äärelle. Tätä laadullista tutkimusta varten haastateltiin 24 sosiaalialan ammattilaista, jotka työskentelevät eri toimipaikoissa eri puolilla Suomea. Suurimmalla osalla oli yliopistotutkinto sosiaalityöstä. Menetelmänä käytettiin aineistolähtöistä sisällönanalyysia. Asiantuntijuus alkaa useimmiten yhteiskunnallisen ilmiön (eli ongelmapelaamisen) hahmottamisesta asiakkaiden kertomusten ja omien kokemusten perusteella.Asiantuntijuutta tarvitaan myös asiakkaan kohtaamisessa ja rahapelaamisen puheeksiotossa. Moni haastateltava piti rahapelaamisesta kysymistä tärkeänä, vaikka kaikki eivät aina muistaneet tehdä sitä. Asiantuntijuus ei ollut pelkästään yhden työntekijän varassa, vaan yhteistyötä tekemällä hyödynnettiin kollegoiden monipuolista asiantuntijuutta ja muiden ammattilaisten osaamista.

\section{JOHDANTO}

Rahapelaamisen mahdollisuuksien kasvaessa ja rahapelien saatavuuden lisääntyessä sosiaalialalla toimivat työntekijät tulevat todennäköisesti kohtaamaan rahapeliongelmista kärsiviä asiakkaita, mutta heillä ei aina ole tarvittavaa asiantuntijuutta tarttua ongelmapelaamiseen (Engel ym. 2012, 321). Vuonna 2019 15-74-vuotiaista suomalaisista noin 112000 henkilöllä oli rahapeliongelma, ja todennäköinen rahapeliriippuvuus oli noin 52000 henkilöllä (Salonen ym. 2020, 9).

Ongelmapelaajaa ei välttämättä tunnista ulkoisen olemuksen perusteella, kuten vaikkapa alkoholistia tai huumeidenkäyttäjää, ja puhuminen rahape- laamisesta ja siihen liittyvistä kielteisistä seurauksista voi olla vaikeaa asiakkaalle häpeän ja leimaantumisen pelon takia. Sosiaalialalla toimivan työntekijän asiantuntijuutta tarvitaan tällöin asiakkaan ongelman tunnistamisessa, hänen auttamisessaan ja ohjaamisessaan oikeanlaisten palvelujen äärelle.

Sosiaalialan ammattilaiset toimivat aitiopaikalla, koska he saavat työssään "ensikäden kokemuksellista tietoa" erilaisista yhteiskunnallisista ongelmista (Pohjola 2011, 215). Ongelmapelaamiseen liittyy erilaisia yksilöllisiä ja sosiaalisia ongelmia, kuten velkaantumista, lähisuhdeongelmia, lähisuhdeväkivaltaa ja lasten kaltoin kohtelua, jotka ovat myös sosiaalityön kohteita (Rogers 2013, 14). Ongelmapelaami- 
seen liittyy usein myös muita ongelmia, kuten päihteiden käyttöä ja mielenterveyshäiriöitä (esimerkiksi masennusta ja itsemurha-ajatuksia) (Momper 2010, 144). Sosiaalityöntekijät ovatkin pitkään työskennelleet päihteiden käytöstä kärsivien asiakkaiden kanssa ja tehneet yhteistyötä päihdepalvelujen kanssa (Manthorpe ym. 2018, 187). Sen sijaan ongelmapelaajien kohtaamisesta sosiaalialalla tiedetään vasta vähän, samoin ongelmapelaamisen ja rahapeliriippuvuuden hoitoon erikoistuneiden palvelujen konsultaatioista (Rogers 2013; Egerer 2013; Castrén ym. 2016; Heiskanen \& Egerer 2018; Manthorpe ym. 2018).

Riippuvuuksista kärsiviä asiakkaita kohdataan muun muassa mielenterveys- ja päihdetyössä, aikuissosiaalityössä, nuorisotyössä, lastensuojelutyössä, vanhustyössä ja maahanmuuttajatyössä. Aiemmin sosiaalityöntekijöiden ammattikunnalla on nähty olevan enemmän tietoa sosiaalisista ongelmista kuin asiakaskunnalla ja näin ollen ammattikunnalle on muodostunut auktoriteettiasema (Raitakari 2002, 48). Uudempien sosiaalisten ongelmien kohdalla tietoa tai suoria toimintaohjeita ei välttämättä olekaan käytettävissä ja asiantuntijat joutuvat aktivoitumaan ja perehtymään uusiin ilmiöihin hankkimalla niistä lisätietoa ja ehkä myös selittelemään tekemisiään asiakkaalle (Eräsaari 2002a, 55). Nykypäivänä asiantuntijuutta ei enää tarkastella yksinään sidoksissa ammattikuntaan, tieteeseen tai instituutioihin (Saaristo 2000, 31). Asiantuntijuus ei ole enää kaikkitietävää ja moderneihin yhteiskuntapilareihin kytkeytyvää: se voi perustua kokemuksellisuuteen, paikallisuuteen, sukupolvisuuteen, pieniin ja suuriin yhteisöllisyyden muotoihin ja muuttoliikkeisiin.

Artikkelissa tarkastelemme asiantuntijuuden muodostumista sosiaalialalla toimivien ammattilaisten parissa, kun asiakkaana on ongelmapelaaja. Laadullista tutkimusta varten on haastateltu 24 sosiaalityöntekijää, -ohjaajaa ja -terapeuttia, jotka toimivat eri puolilla Suomea. Suurimmalla osalla haastateltavista oli korkeakoulututkinto sosiaalityöstä ja muilla oli ammattikorkeakoulututkinto tai opistotasoinen tutkinto. Halusimme tutkimuksen avulla selvittää, mitä sosiaalialan ammattilaiset tietävät rahapelaamisen ilmiöstä ja sen haitallisuudesta, minkälaisissa työtilanteissa he kohtaavat ongelmapelaajia, ja kuinka he auttavat ongelmallisesti pelaavia asiakkaitaan. Asiantuntijuutta koskevat tutkimuskysymyksemme ovat seuraavat: 1) mistä elementeistä sosiaalialan työntekijöiden asiantuntijuus rakentuu suhteessa ongelmapelaamiseen, 2) miten ongelmapelaaminen tunnistetaan sosiaalialalla ja 3) minkälaista asiantuntijuutta syntyy yhteistyössä muiden ammattilaisten kanssa, kun tarkoituksena on auttaa asiakas oikeiden palvelujen piiriin.

\section{Mitä ASIANTUNTIJUUDELla TARKOITETAAN?}

Asiantuntijuuden määrittely ei ole helppoa. Se voidaan liittää asiantuntemuksen, tietämisen ja osaamisen käsitteisiin, mutta asiantuntijuuden käsite on kytköksissä myös aikaan ja paikkaan sekä yksilöihin ja yhteisöihin, jotka pyrkivät sitä määrittelemään. Asiantuntijuutta on tarkasteltu osana modernin ja postmodernin yhteiskunnan toimintaa ja suhteessa kulttuurisiin käsityk- 
siin (Raitakari 2002; Juhila 2006; Fook 2016). Modernissa yhteiskunnassa asiantuntijat ovat olleet toiminnan välttämätön osa ja asiantuntijakunnilla eli professioilla on ollut olennaisia yhteiskunnallisia tehtäviä (Pirttilä 2002, 13). Myöhäismodernissa yhteiskunnassa on tapahtunut asiantuntijuuden murros, jolloin professioita vaivaava kysymys on se, pystyvätkö ne vastaamaan nykyisiin ja tuleviin asiantuntijuutta koskeviin haasteisiin (Konttinen 1997, 48-49). Asiantuntija edustaa omia kulttuurisia arvojaan, mutta myös edustamansa instituution ja yhteiskunnan arvoja, kun taas asiakkaalla voi olla niistä poikkeavia arvoja (Juhila 2006, 113). Asiantuntijuus joutuu vastaamaan myös isoihin muutostrendeihin, kuten globalisaation ja transnationaalisuuden kysymyksiin (Juhila 2018, 191). Asiantuntijoiden on huomioitava työssään paikallisuuden, liikkuvuuden, sitoutumisen ja sopeutumisen vaikutukset niin yksilöiden elämässä kuin yhteisöjenkin muodostumisessa ja olemassaolossa.

Todellisuuden voidaan ajatella olevan yhä monimutkaisempi ja asiantuntijuuden yhä monimuotoisempi (Mutka 1998, 183; Eräsaari 2002b, 25). Tällöin ajattelun yksioikoisuus ja vaihtoehdottomuus eivät ole enää mahdollisia, eivätkä tiedon tuottaminen ja jakaminen voi olla pelkästään erikoistuneiden professioiden etuoikeus. Risto Eräsaaren (2002b, 30) mukaan "suljettu asiantuntijuus" on "ankara ja ehdoton strategia, eetos tai mentaliteetti", jolla on selkeä yhteys tietostrategioihin ja -suosituksiin. "Avoin asiantuntijuus" puolestaan on asioihin puuttuvaa, se joutuu kohtaamaan asiat ja ilmiöt, ja sen on tultava osaksi kohde- ja ongelmatilaa (Eräsaari 2002b, 32). Avoimen asiantuntijuuden kannalta on olennaista, että erilaiset tietovarannot täydentäisivät toisiaan ja niistä syntyisi uutta eri ulottuvuuksia saavaa asiantuntijuutta (Saaristo 2000, 147).

Sosiaalityön asiantuntijuus on "monenlaisten ristipaineiden, eri suuntiin vaikuttavien toimien ja toisilleen vastakkaisten yhteiskunnallisten intressien temmellyskenttä” (Mutka 1998, 12). Kirsi Juhilan $(2018,18)$ mukaan sosiaalityö "on lopulta aina kytköksissä siihen yhteiskunnalliseen aikaan, jossa sitä tehdään, erityisesti kunkin aikakauden keskeisiin sosiaalisiin kysymyksiin sekä sosiaalipoliittisiin ja hyvinvointivaltiollisiin linjauksiin". Yhteiskuntaelämä luo alati uusia haasteita sosiaalityölle varsinkin silloin, kun perinteiden noudattamiseen kiinnitetään vähemmän huomiota, usko ja uskomukset käyvät kamppailua keskenään ihmisten mielissä, tietoa on kaupan ilmaiseksi ja maksusta (ks. internet) ja arvot kovenevat. Yksilöt voivat kokea jäävänsä yksin, he eivät enää tiedä kehen tai mihin luottaa ja heille suoriutuminen talousarvoja ihannoivassa yhteiskunnassa voi olla vaikeaa.

Sosiaalityön asiantuntijuuden on määritelty perustuvan muun muassa pitkään teoreettiseen koulutukseen, ammatin kontrolloimaan työjakoon ja työmarkkinoihin, yliopistotasoiseen sosiaalityön koulutukseen, eettiseen koodistoon ja osaamiseen, kollegiaalisiin järjestöihin ja altruistiseen motivaatioon (Mutka 1998, 40; Sipilä 2011, 19). Sosiaalityöntekijöillä tulee olla "tietämisen asiantuntijuutta" esimerkiksi lainsäädännöllisistä kysymyksistä ja eri virastojen vastuulla olevista asioista, mutta he voivat hyödyntää keskustel- 
lessaan asiakkaan kanssa myös "tietämättömyyden asiantuntijuutta", jolloin he kysyvät asiakkaalta tämän arvoista ja toiminnasta ja samalla auttavat tätä sosiaalityön viitekehyksessä (Gaiswinkler \& Roessler 2009, 221-222).

Asiantuntijuus liittyy modernissa tulkintakehyksessä useimmiten myös vallan kysymykseen. Asiantuntijalla on mahdollisuus vallan käyttöön, mikä näkyy esimerkiksi suhteessa asiakkaaseen. Kyseinen valta voidaan perustella ja oikeuttaa esimerkiksi asiakkaan "ohjaamisena takaisin yhteiskuntaan", jolloin asiantuntija voi määritellä, minkälaista elämää kohti asiakkaan tulisi suuntautua (Raitakari 2002，49，47). Vaikka sosiaalityöntekijät yrittävät saada aikaiseksi muutosta asiakkaissaan ja heidän elämässään, he voivat myös haluta säilyttää oman statuksensa ja työskentelytapansa ja vastustaa muutosta. Lisäksi valtaa voi käyttää suhteessa yhteistyökumppaneihin tekemällä statuksensa ja asemansa heille tiedoksi (Webb 2000, 1-2). Sosiaalityötä voidaan pitää myös poliittisena toimintana, jonka täytyy vastata haasteisiin, joita hallituksen vaihtuvat prioriteetit tuottavat (Gilbert \& Powell 2010, 4).

Asiantuntijuus ei ole kuitenkaan mikään "pysyväisluonteinen ominaisuus", vaan sillä on vuorovaikutuksellinen luonne (Saaristo 2000, 34). Asiantuntijuus voi vaihdella suhteessa muuttuviin ja ennakoimattomiin tilanteisiin sekä henkilökohtaisiin arvoihin ja ideologioihin (Fook ym. 1997, 400). Sosiaalityössä asiantuntijuus voi olla "horisontaalista", jolloin sosiaalityöntekijän ja asiakkaan asiantuntemus eivät sulje pois toisiaan. Horisontaalisessa suhteessa asetutaan samalle tasolle ja kuunnellaan toisiaan. (Juhila 2006, 137-138.) Sosiaalityön asiantunti- juus voi olla myös "vertikaalista", jolloin sosiaalityöntekijällä on sellaista tietoa,jota asiakkaalla ei ole, ja tiedon avulla sosiaalityöntekijä voi auttaa asiakasta ja myös määritellä tälle muutoksen suunnan, jota kohti pyrkiä (Juhila 2006, 84-85).

Sosiaalityöntekijöillä on myös tietoa, jota välttämättä ei ole puettu sanoiksi tai kirjoitettu ylös. Hiljainen tieto ei ole yksinään "sisäistä kokemustietoa", vaan se on "sanoittamaton, formuloimaton tiedon muoto, joka on suodattunut erilaisista tiedon lajeista ja varastoitunut kantajaansa" (Pohjola 2007, 12). Hiljainen tieto voi olla myös ajattelua, asioiden pohdintaa ja miksi-kysymysten pohdiskelua (Sipilä 2011, 127). Sosiaalityössä se voi olla 'kokemuksen, uskomusten, mielikuvien ja teoreettisesti opitun pohjalta muotoutunutta osaamista ja ammattitaitoa" (Pohjola 2007, 12). Myös asiakkaalla on hiljaista tietoa asioista, joista hän ei välttämättä uskalla puhua ääneen tai joita hän ei tunnista ongelmallisiksi itselleen.

Anneli Pohjolan $(2007,13)$ mukaan sosiaalityössä asiantuntijuus "pohjautuu kykyyn yhdistää monia tietoperustoja kokonaisuudeksi". Näin ollen tieto rakentuu "olosuhdetietoon ja toimintayhteyksiin" ja kytkeytyy aikaan, paikkaan, kulttuuriin, yhteisöihin ja vuorovaikutukseen (Pohjola 2007, 13). Yhteiskuntaelämä on kuitenkin täynnä ilmiöitä, joiden ongelmallisuutta voi olla vaikea käsittää tai joiden merkitystä asiakkaalle on haasteellista ymmärtää. Ilmiöt voivat kätkeä taakseen sosiaalisia ongelmia, joiden vaikutukset yksilön elämään ovat kauaskantoisia, mutta joista ei välttämättä ole yleistä tietoa tai kokemusta omassa ammatissa. Tällaiset ilmiöt (ja sosiaaliset ongelmat) vaativat sosiaalialan työntekijältä perehtymistä, 
usein oma-aloitteisuutta ja mielenkiintoa, jotta asiakasta saadaan autettua.

\section{TUTKIMUKSEN TOTEUTUS}

Tutkimusta varten haastateltiin 24 sosiaalityöntekijää, -ohjaajaa ja -terapeuttia. ${ }^{1}$ Haastattelut tehtiin eri toimipisteissä, jotta saataisiin mahdollisimman monipuolinen kuva sosiaalialan tehtävistä sekä sosiaali- ja päihdetyön palveluista ja asiakkuuksista. Puolet haastateltavista toimi aikuissosiaalityössä ja moni heistä työskenteli 18-29-vuotiaiden nuorten parissa. Noin puolet haastateltavista teki päihdetyötä ja muiden haastateltavien työtehtävät liittyivät erityisryhmiin (kuntoutujat, maahanmuuttajat ja vangit). Haastattelut toteutettiin 11 maakunnassa joko yhdellä tai kahdella paikkakunnalla. Paikkakuntien koko vaihteli hieman yli 3000 asukkaan kunnista aina yli 200000 asukkaan kuntiin.
Alun perin tarkoituksenamme oli haastatella pelkästään sosiaalityöntekijöitä, joilla oli ollut ongelmallisesti rahapelejä pelaavia asiakkaita. Soittokierros eri paikkakunnille osoitti, että haastateltaviksi ajatelluista henkilöistä moni teki sosiaalityöntekijän tehtäviä, mutta kaikilla ei ollut ammatin vaatimaa pätevyyttä. Suurin osa haastateltavista oli kuitenkin opiskellut sosiaalityön maisteriksi tai omasi kaksoistutkinnon (maisterin tutkinto ja ammattikorkeakoulututkinto) (Taulukko 1). Ne, jotka olivat opiskelleet sosiaalikasvattajiksi, sosionomeiksi ja diakoneiksi, tekivät sosiaalityöntekijän sijaisuuksia tai toimivat sosiaaliterapeutteina tai -ohjaajina. Päihdetyötä tekevillä ammattilaisilla saattoi olla tutkinnon/tutkintojen lisäksi myös kognitiivisen psykoterapeutin koulutus tai suoritettuna muita terapiaopintoja (esimerkiksi lyhytterapiasta tai perheterapiasta). Muutama haastateltava kertoi saaneensa koulutusta rahapelaamiseen liittyvistä haitoista tai rahapeliriippuvuu-

Taulukko 1. Haastateltavien koulutus, ammattinimikkeet ja lukumäärä

\begin{tabular}{|l|l|l|l|}
\hline Haastateltavat & Koulutus & Ammattinimike & Lukumäärä \\
\hline $\begin{array}{l}\text { RS3, RS4, RS6, } \\
\text { RS7, RS8, RS9, } \\
\text { RS10, RS15, RS16, } \\
\text { RS19 }\end{array}$ & Sosiaalityön maisteri & Sosiaalityöntekijä & 10 \\
\hline RS20 & $\begin{array}{l}\text { Sosiaalityön maisteri ja } \\
\text { ammattikorkeakoulututkinto }\end{array}$ & Sosiaalityöntekijä & 1 \\
\hline $\begin{array}{l}\text { RS12, RS13, RS14, } \\
\text { RS24 }\end{array}$ & Ammattikorkeakoulututkinto & Sosiaalityöntekijä & 4 \\
\hline RS1 & Sosiaalityön opiskelija & Sosiaalityöntekijä & 1 \\
\hline RS23 & Sosiaalityön maisteri & Sosiaaliterapeutti & 1 \\
\hline RS22 & $\begin{array}{l}\text { Sosiaalityön maisteri ja } \\
\text { ammattikorkeakoulututkinto }\end{array}$ & Sosiaaliterapeutti & 1 \\
\hline RS18 & Ammattikorkeakoulututkinto & Sosiaaliterapeutti & 1 \\
\hline RS2 & Opistotason tutkinto & Sosiaaliterapeutti & 1 \\
\hline RS5 & Opistotason tutkinto & Sosiaaliohjaaja & 1 \\
\hline RS11, RS21 & Ammattikorkeakoulututkinto & Sosiaaliohjaaja & 2 \\
\hline RS17 & $\begin{array}{l}\text { Sosiaalityön maisteri ja } \\
\text { ammattikorkeakoulututkinto }\end{array}$ & $\begin{array}{l}\text { Muu sosiaalialan } \\
\text { ammattilainen }\end{array}$ & 1 \\
\hline & & & \\
\hline
\end{tabular}


den hoidosta. Kaikilla haastateltavilla oli ollut vähintään yksi asiakas, jolla oli ongelmia rahapelaamisen kanssa.

Haastateltavat rekrytoitiin ottamalla heihin suoraan yhteys puhelimitse tai sähköpostitse. Heitä pyydettiin osallistumaan tutkimushankkeeseen, jonka tarkoituksena oli selvittää, mitä sosiaalityöntekijät tietävät rahapelaamisen ilmiöstä, ongelmapelaamisesta ja rahapelihaitoista. Saatuaan haastateltavan suullisen tai kirjallisen suostumuksen haastattelija sopi haastattelun ajankohdasta ja -paikasta. Haastattelut tehtiin syksyllä 2016 ja ne ovat pituudeltaan 25-70 minuuttia. Haastattelujen pituuteen näytti vaikuttavan ongelmallisesti pelaavien asiakkaiden määrä, mutta myös haastateltavan uran pituus.

Tutkimusmenetelmänä on käytetty aineistolähtöistä sisällönanalyysia (Tuomi \& Sarajärvi 2002; Elo \& Kyngäs 2007) ja laadullisen analyysin apuna Atlas. ti-ohjelmaa. Aineistolähtöinen sisällönanalyysi on kolmivaiheinen prosessi, jossa aineisto pelkistetään (haastatteluaineisto pilkotaan osiin ja osat nimetään), ryhmitellään (samaa asiaa tarkoittavat käsitteet ryhmitellään yhteen ja ryhmät nimetään) ja käsitteellistetään (edetään teoreettisiin käsitteisiin ja johtopäätöksiin). Lopuksi käsitteistä muodostetaan yhdistävä luokka, jotta saadaan vastauksia tutkimustehtävään. (Tuomi \& Sarajärvi 2002, 110-115.)

Analyysia on edeltänyt perusteellinen perehtyminen haastatteluaineistoon, joka on luettu monta kertaa läpi. Analyysissa olemme edenneet induktiivisesti eli käytännössä aineisto on koodattu yksittäisestä yleiseen (Elo \& Kyngäs 2007, 110; Tuomi \& Sarajärvi 2002, 95-
97). Analyysiyksikkönä käytimme useita lauseita sisältävää ajatuskokonaisuutta,joka oli yleensä vastaus haastattelijan kysymykseen (Tuomi \& Sarajärvi 2002, 112). Aineiston analyysin tavoitteena on ollut lukea asiantuntijuuden muodostumista ja kehittymistä haastatteluista ja hyödyntää haastateltavien omia sanoja erilaisten asiantuntijapositioiden, raha- ja ongelmapelaamista koskevan tiedon keruun ja kerryttämisen sekä eri toimialojen työskentelytapojen ja yhteistyön auki kirjoittamisessa.

Alla olevissa taulukoissa analyysia voi seurata luokittain. Alaluokka edustaa pelkistettyä muotoa haastattelupuheesta. Haastatteluesimerkkejä ei taulukoihin ole enää lisätty, sillä niitä voi lukea haastatteluotteista. Yläluokka kiteyttää alaluokan esimerkit ja toimenpiteet käsitteiksi, jotka ovat mahdollisimman kuvailevia. Pääluokan käsitteet tiivistävät aineiston päätuloksiksi, jotka on raportoitu tässä artikkelissa. Yhdistävät luokat ovat "asiantuntijuuden muodostuminen", "työntekijöiden kokemuksia rahapeliongelman käsittelystä" ja "asiantuntijuus yhteistyössä".

Haastattelujen toisistaan poikkeavat pituudet, haastateltavien tapa vastata haastattelijan kysymyksiin (vrt. lyhyesti tai pitkästi tai asian ulkopuolelta), heidän työtehtäviinsä liittyvät näkökulmat ja heidän erilaiset koulutuspolkunsa toivat omat haasteensa haastattelujen analyysiin. Näistä haasteista huolimatta koko haastatteluaineistosta on etsitty vastauksia tutkimuskysymyksiin. Tarkoituksenamme oli myös saada selville, missä kaikkialla sosiaalialalla voidaan kohdata ongelmallisesti pelaavia henkilöitä. 
Taulukko 2. Asiantuntijuuden muodostuminen

\begin{tabular}{|c|c|c|}
\hline ALALUOKKA & YLÄLUOKKA & PÄÄLUOKKA \\
\hline $\begin{array}{l}\text { Asiakkaiden kertomukset } \\
\text { Näkemykset rahapelaamisesta } \\
\text { Kokemukset ja muistot } \\
\text { Opiskelu ja koulutus }\end{array}$ & $\begin{array}{l}\text { Asiakkuudet } \\
\text { Ilmiön sanoittaminen } \\
\text { Osaamisen kehittäminen }\end{array}$ & $\begin{array}{l}\text { RAHAPELAAMISEN } \\
\text { ILMIÖN YMMÄRRYKSEN } \\
\text { LÄHTÖKOHDAT }\end{array}$ \\
\hline $\begin{array}{l}\text { Toimeentulohakemus } \\
\text { Tiliotteet } \\
\text { Palvelutarvearviointi } \\
\text { Kartoituslomakkeet }\end{array}$ & $\begin{array}{l}\text { Asiakirjojen tarkastelu } \\
\text { Arviointi ja kartoitus }\end{array}$ & $\begin{array}{l}\text { ASIAKKAIDEN } \\
\text { RAHAPELAAMINEN }\end{array}$ \\
\hline $\begin{array}{l}\text { Varhainen tutustuminen } \\
\text { rahapelaamiseen } \\
\text { Sosiaalisten verkostojen } \\
\text { puuttuminen } \\
\text { Koulutuksen puute } \\
\text { Työttömyys } \\
\text { Mielenterveys- ja } \\
\text { terveysongelmat } \\
\text { Alkoholin käyttö }\end{array}$ & $\begin{array}{l}\text { Asiakkaiden elämää } \\
\text { heikentävät tekijät } \\
\text { Moniongelmaisuus }\end{array}$ & $\begin{array}{l}\text { ONGELMAPELAAMISELLE } \\
\text { ALTISTAVAT TEKIJÄT }\end{array}$ \\
\hline $\begin{array}{l}\text { Velkaantuminen } \\
\text { Lainaaminen } \\
\text { Varastaminen } \\
\text { Riitelyt } \\
\text { Av(i)oeron uhka } \\
\text { Läheisten kielteiset } \\
\text { kokemukset }\end{array}$ & $\begin{array}{l}\text { Taloudelliset ongelmat } \\
\text { Ihmissuhdeongelmat }\end{array}$ & $\begin{array}{l}\text { RAHAPELAAMISEN } \\
\text { HAITALLISET } \\
\text { SEURAUKSET }\end{array}$ \\
\hline
\end{tabular}

Taulukko 3. Työntekijöiden kokemuksia rahapeliongelman käsittelystä

\begin{tabular}{|l|l|l|}
\hline ALALUOKKA & YLÄLUOKKA & PÄÄLUOKKA \\
\hline $\begin{array}{l}\text { Ajanvaraus } \\
\text { Päivystys } \\
\text { Lähete }\end{array}$ & Asiakkaan avunsaannin reitit & $\begin{array}{l}\text { ASIAKKAAN JA } \\
\text { TYÖNTEKIJÄN } \\
\text { KOHTAAMINEN }\end{array}$ \\
\hline $\begin{array}{l}\text { Tiliotteet } \\
\text { Laskut } \\
\text { Rahapelaamisesta kysyminen } \\
\text { toimenpiteenä }\end{array}$ & $\begin{array}{l}\text { Rahapelaamisen puheeksiotto } \\
\text { Kysyminen talousongelmista } \\
\text { Puheeksioton pois jättäminen }\end{array}$ & $\begin{array}{l}\text { RAHAPELIONGELMAN } \\
\text { PUHEEKSI OTTAMINEN }\end{array}$ \\
\hline $\begin{array}{l}\text { Asiakkaan syyllisyys ja häpeä } \\
\text { Työntekijä ei saa avattua } \\
\text { keskustelua } \\
\text { Asiakas ei tunnista tai } \\
\text { tunnusta ongelmaansa }\end{array}$ & $\begin{array}{l}\text { Asiakkaan vaikeus puhua } \\
\text { rahapeliongelmastaan } \\
\text { Työntekijä ei saa asiakasta } \\
\text { avautumaan }\end{array}$ & $\begin{array}{l}\text { KOMMUNIKOINTI- } \\
\text { VAIKEUDET } \\
\text { TYÖNTEKIJÄN JA } \\
\text { ASIAKKAAN VÄLILLÄ }\end{array}$ \\
\hline
\end{tabular}


Taulukko 4. Asiantuntijuus yhteistyössä

\begin{tabular}{|l|l|l|}
\hline ALALUOKKA & YLÄLUOKKA & PÄÄLUOKKA \\
\hline $\begin{array}{l}\text { Työskentely työtovereiden } \\
\text { kanssa } \\
\text { Työskentely muiden } \\
\text { ammattilaisten kanssa } \\
\text { Työskentely asiakkaiden } \\
\text { parissa }\end{array}$ & $\begin{array}{l}\text { Tiimityö } \\
\text { Eri alan ammattilaisten } \\
\text { yhteistyö } \\
\text { Roolit }\end{array}$ & $\begin{array}{l}\text { MONIAMMATTILLISEN } \\
\text { TYÖSKENTELYN MUODOT }\end{array}$ \\
\hline $\begin{array}{l}\text { Yhden luukun palvelut } \\
\text { Konsultoidaan } \\
\text { ongelmapelaajien tuki- ja } \\
\text { hoitopalveluja } \\
\text { Toinen ammattilainen } \\
\text { konsultoi asiakkaan puolesta }\end{array}$ & $\begin{array}{l}\text { Asiakkaan puolesta tehtävät } \\
\text { yhteydenotot } \\
\text { Yhteydenotto } \\
\text { erityispalveluihin } \\
\text { Asiakkaan auttaminen toisen } \\
\text { ammattilaisen aloitteesta }\end{array}$ & KONSULTOINTI \\
\hline $\begin{array}{l}\text { Luodaan tukiverkosto } \\
\text { asiakkaan ympärille } \\
\text { Työntekijä osana } \\
\text { ammattilaisverkostoja }\end{array}$ & $\begin{array}{l}\text { Verkostoituminen } \\
\text { Työskentely verkostoissa }\end{array}$ & VERKOSTOTYÖ \\
\hline $\begin{array}{l}\text { Työntekijä ohjaa asiakkaiden } \\
\text { vertaistuki- tai } \\
\text { kuntoutusryhmiä }\end{array}$ & $\begin{array}{l}\text { Vertaistukiryhmät } \\
\text { Kuntoutusryhmät }\end{array}$ & OHJAUSTYÖ \\
\hline
\end{tabular}

Haastateltavien suostumusta pyydettäessä heitä informoitiin haastattelumateriaalin käytöstä tutkimustyöhön. Haastateltavilla oli mahdollisuus perua haastattelu milloin tahansa niin halutessaan. Tutkimukseen liittyvät asiat (tarkoitus, tutkimuskysymykset, tavoite) käytiin läpi vielä kerran ennen haastattelun alkua, jotta haastateltava ymmärsi miksi haastattelu tehdään ja kuinka haastatteluaineistoa käytetään tutkimiseen. Haastatteluaineistoon viitataan merkinnällä "RS" (eli "Rahapeliongelmat sosiaalityössä"-tutkimushanke) ja numeroinnilla, joka viittaa haastattelujen tekojärjestykseen.

Artikkelissa käytetään haastattelusitaatteja "aineistoa kuvaavina esimerkkeinä" (Eskola \& Suoranta 2000, 175). Haastatteluaineiston anonymisoinnilla on haluttu suojata haastateltavien ja heidän asiakkaittensa yksityisyyttä (Kuula 2006, 124). Haastattelujen puhekielisyys on korvattu kirjakielellä, jotta haastateltavien puhetyyliä tai murretta ei voida tunnistaa. Mahdolliset henkilöiden, toimipaikkojen ja kuntien nimet on poistettu sitaateista. Sitaattien valinnassa on huomioitu se, että haastateltavien asiakkaat elävät vaikeassa sosiaalisessa tilanteessa ja he ovat haavoittuvia ongelmiensa vuoksi (vrt. Järvinen-Tassopoulos 2011).

\section{AsIANTUNTIJUUS ALKAA ILMIÖN HAHMOTTAMISESTA}

Sosiaalialan muuttuvaan asiakkuuteen liittyy erilaisia haasteita: toimintaympäristöt muuttuvat, erityistä tukea tarvitsevat ryhmät kasvavat ja sosiaaliset ongelmat kietoutuvat yhteen ja monimutkaistuvat (Lindh ym. 2018, 11). Tämä mielessä kysyimme haastateltavilta, minkälainen ilmiö rahapelaaminen on, ja minkälaisia yksilöä koskevia haittoja siihen saattaa liittyä. Monet haastateltavista puhuivat rahapelaami- 
sesta asiakkaittensa kokemusten perusteella, mutta joskus myös henkilökohtaisesti tuntemiensa rahapelaajien elämäntarinoiden avulla. Jotkut haastateltavista puhuivat rahapeliongelmista tai ongelmapelaamisesta.

\begin{abstract}
”No, ilmiönähän [rahapelaaminen] on siinä mielessä mielenkiintoinen juttu, että se on sekä piilossa että esillä. Se on kaksijakoinen juttu. Se on esillä mainoksissa ja ääninä ja kioskin tilankäyttönä ja myyjien puheessa sekä lottoajien kulttuurissa ja haaveissa. Sanotaan, että "on lottovoitto syntyä Suomeen". Tällaisia asioita on esillä ja ongelmina [rahapelaaminen] on piilossa. Se kaksijakoisuus on mielenkiintoinen ilmiö sinällään.” (RS2)
\end{abstract}

Haastateltava tarttuu aiheeseen rahapelaamisen tarjonnan kautta ja kuvailee samalla suomalaiseen rahapelikulttuuriin liittyviä toiveita ja myyttejä unohtamatta rahapeliongelmia. Minna Kivipellon ja Paula Saikkosen (2013, 16) mukaan "käytännön asiakastyössä muodostuu informaatiota, joka ei ole vielä tietoa, ennen kuin se on käsitelty ja tulkittu". Sosiaalialan ammattilainen voi myös hyödyntää asiakastyössä sitä tietoa, joka on muodostunut hänelle havainnoimalla arkielämää ja sosiaalista ympäristöä sekä hänen omista mielikuvistaan. Havainnointiin ja mielikuviin perustuva tieto voi auttaa sosiaalialan työntekijää hahmottamaan paremmin asiakkaan ongelmaa, joka ei ehkä ole ensikädeltä tuttu.

Jotkut haastateltavista peilasivat rahapelaamisen ilmiötä lapsuuden tai nuoruuden muistojen kautta:

"Jotenkin itse muistan, että pajatsot ja muиt [rahapelit] ovat olleet olemassa [lapsuu- dessa]. Omat vanhempani eivät pelanneet, mutta [sukulainen] on laitellut joitain markkoja jonnekin ja käynyt lottoamassa. Tällainen [rahapelaaminen] ei leimautunut mitenkään negatiiviseksi asiaksi. Tuumin tässä, että varmaan olen lapsena nähnyt sitä mallia, että rahapelaaminen on olemassa. Nythän rahapelejä on vähän viety pelisalinkin puolelle ja niitä punaisia neliöitä on teipattu lattiaan, etteivät lapset ole siinä lähellä. Mutta niitä vaikutteita voi tulla muutenkin. Kyllä se varmaan lisää rahapelaamista, jos on kasvanut pienestä pitäen tiettyyn [rahapeli]kulttuuriin”. (RS8)

Henkilökohtaisiin kokemuksiin viittaaminen voidaan tulkita "hiljaisesta tiedosta" ammentamiseksi. Hiljainen tieto liittyy "ihmisten muistiin, kokemuksiin, tuntemuksiin, osaamiseen, mielikuvitukseen, toimintaan, menettelytapoihin tavalla, joka tekee siitä henkilökohtaista" (Hänninen 2006, 107). Haastateltavat, jotka muistelivat rahapelaamista lapsuudessaan ja nuoruudessaan, toivat esille suomalaisen rahapelikulttuurin muuttumisen erityisesti rahapelaamisen rajoittamisen tasolla.

Moni haastateltava totesi rahapelaamisen siirtyneen yhä enemmän internetiin ja erityisesti nuorten aikuisten asiakkaiden olevan kiinnostuneita internetin rahapeleistä ja digitaalisista peleistä.Asiakkaiden kertoman perusteella rahapelaaminen näyttäytyi sosiaalityöntekijöille hetken huumana, jännityksen etsimisenä ja alun perin harmittomana ajanvietteenä, josta se kehittyy ongelmalliseksi. Haastateltavat eivät sitoneet rahapelaamista tiettyyn sukupuoleen tai ikään, vaikka moni haastateltava nimesi erilaisia pelaajaryhmiä (esimerkiksi nuoret urheilijat ja ikäihmiset) asiakkuuksiensa perusteella. 
Ongelmapelaamisesta ja rahapelaamisen aiheuttamista haitoista haastateltavat kertoivat joko nykyisten tai aiempien työtehtäviensä kautta. Rahapelaamisen kehittymiselle ongelmalliseksi löytyi erilaisia selittäviä tekijöitä. Altistaviksi tekijöiksi ongelmapelaamiselle katsottiin varhainen tutustuminen rahapelaamiseen jonkun aikuisen kautta, rikkonainen lapsuus (esimerkiksi lastensuojeluasiakkuus perheessä), sosiaalisten verkostojen puuttuminen tai yksinäisyys. Muita haitallisia syitä rahapelaamiseen vaikuttivat olevan toimettomuus, luulo taloudellisen tilanteen kohentumisesta rahapelivoittojen avulla, ikävien asioiden ja tilanteiden välttely tai toive rikastumisesta. Myös sairauksien, kuten Parkinsonin taudin tai kaksisuuntaisen mielialahäiriön, katsottiin lisäävän yksilölle haitallista rahapelaamista. Joillain asiakkailla oli samanaikaisesti päihdeongelma tai muita riippuvuuksia. Alkoholi vaikutti lisäävän joidenkin asiakkaiden rahapelaamista.

Eniten haastatteluissa puhuttiin asiakkaiden taloudellisista ongelmista. Rahapelaaminen aiheutti usein sen, että asiakkaan tulot menivät rahapeleihin ja rahaa ei jäänyt päivittäisiin tarpeisiin. Moni rahoitti rahapelaamisensa pikavipeillä, kulutusluotoilla, toimeentulotuella, opintolainalla tai muilta lainaamillaan rahoilla. Pahimmillaan asiakkaat varastivat ja kavalsivat rahaa voidakseen jatkaa pelaamista. Velkaantumisen seurauksena asiakkaat voivat menettää luottotietonsa ja saada maksuhäiriömerkinnän. Usein läheisille ei kerrottu taloudellisista ongelmista, ja velkojien lähettämät laskut piilotettiin. Heikko taloudellinen tilanne vaikuttaa myös asumiseen: vuokrat jäävät maksa- matta, sähkölaskuja ei saada maksettua ja asiakkaita (perheineen) uhkaa häätö kodista.

Ongelmallinen rahapelaaminen vaikuttaa myös ihmissuhteisiin. Haastateltavat mainitsivat parisuhde- ja perheongelmat, jotka kuormittavat ongelmapelaajia ja heidän läheisiään. Ongelmapelaaja ja puoliso riitaantuvat, ja parisuhde kriisiytyy rahapelaamisen takia. Ongelmapelaaja yrittää salata rahapelaamisensa puolisoltaan ja tämän saadessa ongelman selville, luottamus pelaajaan katoaa. Puoliso saattaa uhata erolla tai ottaa av(i)oeron. Pelatessa on vaikea keskittyä perheen asioihin, läheiset huomauttelevat rahapelaamisesta ja lapset saattavat jäädä ilman huomiota ja hoitoa. Nuorten aikuisten tapauksessa heidän vanhempansa saattavat maksaa heidän rahapelaamisesta aiheutuneita velkojaan tai isovanhemmat voivat tarjota heille ruokaa, kun rahaa ei enää ole pelaamiselta.

\section{Asiakkaan kohtaAminen Ja ONGELMAN PUHEEKSIOTTO}

Virastoissa esiintyy kahdentyyppisiä kohtaamisia, jotka ovat joko päämäärättömiä tai päämäärällisiä. Esimerkiksi viranomaisten ja asiakkaiden kohtaamisilla on päämäärä, koska ne tähtäävät palveluiden vaihtoon tai välittämiseen (Eräsaari 1995, 184). Sosiaalityötä tehdään erilaisissa institutionaalisissa tiloissa, joita voivat olla virastojen toimistohuoneet, virtuaalitoimistot, laitosmaiset ympäristöt, puolimatkan paikat ja matalan kynnyksen paikat (Juhila 2018, 108-139). 
Haastatteluaineistossa kohtaamispaikkoja ovat useimmiten virastojen toimistohuoneet, mutta asiakkaita kohdataan myös puolimatkan (esimerkiksi vastaanottokeskuksessa ja kuntoutusyksikössä) ja matalan kynnyksen paikoissa (esimerkiksi neuvontapalvelussa tai verkkopalvelussa).

Asiakaspalvelutyössä korostetaan tasavertaisen kohtaamisen ja asiakaslähtöisyyden merkitystä. Asiakkaan kohtaaminen on inhimillistä vuorovaikutusta, mutta asiakastyötä säätelevät myös yhteiskunnalliset ja eettiset rakenteet. (Mönkkönen 2018, 16-17.) Sosiaalityössä korostetaan usein asiakaslähtöisyyden periaatetta, mikä perustelee sitä, että työn lähtökohtana tulisi olla se tieto, joka syntyy asiakkaiden olemisen ja elämisen paikoissa (Juhila 2006, 106). Asiakkaan kuulluksi tuleminen ja se, että hän tulee otetuksi vakavasti, voivat tuottaa osallisuuden kokemusta (Juhila 2006, 119).

Kohtaamisia on aineiston perusteella erityyppisiä: asiakas kutsutaan käymään, asiakas tulee vastaanotolle ajanvarauksen kautta tai asiakas tulee kuntoutukseen. Haastavinta sosiaalialalla voi olla ongelmallisesti rahapelejä pelaavien asiakkaiden tunnistaminen. Asiakas ei välttämättä hae apua sosiaalipalveluista ensisijaisesti ongelmapelaamiseen, vaan sen aiheuttamiin taloudellisiin haittoihin. Sen sijaan rahapelaamiseen liittyvä ongelma voi olla ensisijainen syy hakeutua päihdepalveluihin.

Esimerkiksi aikuissosiaalityössä, jossa hoidettiin toimeentulohakemuksia vuoden 2016 loppuun asti, asiakkaan rahapelaaminen saattoi tulla ilmi tiliot- teista, jolloin sosiaalityöntekijä pystyi ottamaan aiheen luontevasti puheeksi:

\begin{abstract}
"Yleensä ne ovat vuokrarästitilanteita tai sitten [asiakkaat] tulevat selvittämään velkoja. Siinä vaiheessa, kun lähdetään purkamaan, ja mietitään velkaneuvontaohjausta ja sosiaalista luottoa, niin selvitetään mistä velkaantuminen johtuu ja onko se toistuva uhka, ja voidaanko sosiaalisella luotolla esimerkiksi pelastaa mitään. En muista, että kukaan asiakkaista olisi soittanut minulle pyytäen apua rahapelaamisen takia. [Pyyntö] tulee vasta sitten, kun tongitaan sitä, mihin rahat ovat menneet." (RS12)
\end{abstract}

Aiempien sosiaalialan ammattilaisten osaamista kartoittavien selvitysten perusteella sosiaalityöntekijöiden tietämys rahapeliongelmien ehkäisystä ja hoidosta oli vähäisempää kuin päihdetyöntekijöiden. Rahapelaamisen puheeksiotto mahdollistui, jos asiakkaalla oli "selittämätöntä rahanmenoa" tai hän otti itse rahapeliongelmansa puheeksi (Raiski 2011, 29; Huotari 2009, 128).

Sosiaalityössä rahapelaaminen oli yleensä toissijainen ongelma, sillä asiakkaan ensisijainen ongelma saattoi olla mielenterveysongelma, päihdeongelma, sosiaalinen ongelma tai taloudellinen ongelma. Ongelmapelaaminen tuli esille esimerkiksi taloudellisen tilanteen selvittelyn yhteydessä tai jonkun muun ongelman, sairauden tai asian hoitamisen myötä (Castrén ym. 2016, 421-422).

Rahapelaaminen ja sen aiheuttamat haitat voivat olla hankala aihe asiakkaalle, ja siitä johtuen tämän on vaikea ottaa asia puheeksi itse:

"Varmaan sitten [aikuissosiaalityössä] pitäisi pystyä avaamaan sitä asiaa ja keskus- 
telemaan siitä yhdessä. Täytyy [keskustella rahapelaamisesta], koska siihen liittyy niin paljon syyllisyyttä ja häpeää. Että tavallaan [asiakas] tulisi nähdyksi muunakin kuin vain rahapelaajana, ongelmapelaajana. (...) Varmaan senkin ymmärtäminen, että [ongelmapelaaminen] ei ole sellainen kerrasta poikki -juttu, vaan se vaatii työskentelyä ongelman voittamiseksi. Sellainen motivointi, että [asiakas] lähtee miettimään sitä asiaa ja tekee asialle jotain. Ja ehkä sen toivon antaminen, että kyllä asialle voi tehdä jotakin. Hankala juttu, mutta kyllä tästä voi selvitä eteenpäin.” (RS3)

Keskustelua ongelmasta ei välttämättä synny sosiaalityöntekijän yrityksestä huolimatta:

"Tiedän yhden [asiakkaan], joka varmastikin tulee saamaan häädön. Se asiakastapaus on jäänyt minulle täysin hämäräksi, koska [asiakas] ei suostunut millä̈n tavalla käsittelemään asiaa. (...) Rupesin puhumaan siitä rahapelaamisesta, joka oli siis todella järkyttävää. Siinä oli mennyt tuhansia euroja nettirahapeliin ihan muutamassa illassa. Sen jälkeen [asiakas] sanoi, ettei hän ymmärrä. Okei. Siis monella tapaa yritin lähestyä [rahapeliongelmaa], mutta hän ei suostunut sitä mitenkään käsittelemään ja sitten hän lähti.” (RS1)

Haastatteluotteessa sosiaalityöntekijä ottaa asiakkaan rahapelaamisen puheeksi, muttei saa vastakaikua keskustelunavaukselleen. Kohtaamista ei vaikuta syntyvän, sillä sosiaalityöntekijän ja asiakkaan tavoitteet vaikuttavat olevan ristiriidassa keskenään. Puheeksiottoa ja neuvontaa voidaan pitää tilanteesta riippuen "ammattilaisen velvollisuuksina", "voimaantumisen mahdollistajina" tai "arkaluontoisina vuorovaikutustilanteina" (Renko 2018, 69). Jari Hei- nonen (2012, 218) huomauttaa, että sosiaalityön dialogisuus "ei ole pelkkää kuuntelua ja puhetta, vaan jotakin enemmän, yhteistä luomista, jossa parhaimmillaan molemmat osapuolet oppivat ja voivat jopa muuttaa mielipiteitään ja asenteitaan".

Monet haastateltavista pohtivat sitä, että rahapelaamisesta pitäisi osata kysyä, mutta se saattaa jäädä tekemättä.Asiakas ei itse ota rahapelaamista puheeksi, eikä asiakkaan puheesta kuulu viitteitä asiasta. Puheeksiottoa voi vaikeuttaa myös se, että sosiaalityöntekijä ei koe olevansa tarpeeksi perehtynyt rahapelaamisen ilmiöön (esimerkiksi eri rahapeleihin ja -tiloihin) tai ongelmapelaamisen seurauksiin:
"Ne strukturoidut kyselylomakkeet ovat tosi tärkeitä minulle, koska niissä ihan lu- etellaan rahapelit, kun en osaa kysyä. En oikeasti tiedä, mitä kaikkea voi pelata. Ajattelen, että se rahapelien maailma on niin vieras, kun en ole itse siihen kasvanut. Niin en osaa kysyäkään, mitä kaikkea voisi pelata. (...) Sitten voi kuvitella, että se on [asiakkaalle] helpompi, kun hän ajattelee, että [työntekijä] tietää mitä voi pelata tai hänellä on jokin taju asiasta.” (RS10)

Raija Leppälahden $(2014,48)$ mukaan sosiaalityön asiantuntijuuteen "kuuluu jatkuva ja asteittain etenevä ongelmanratkaisuprosessi, joka on myös kiinteä osa työntekijän oppimisprosessia". Oikeanlainen kohtaaminen sosiaalialan työntekijän ja asiakkaan välillä jää tapahtumatta, jos työntekijä ei koe omaa ammatillista osaamistaan riittäväksi erikoiselta vaikuttavan tai itselleen vieraan ongelman edessä. Kuunteleminen ei riitä, jos ei tiedä miten auttaa asiakasta. 


\section{YHTEISTYÖTÄ ASIAKKAAN HYVÄKSI}

Asiantuntijuutta voidaan tarkastella myös laajemmin sosiaalialan työntekijöiden tekemän yhteistyön näkökulmasta. Yhteistyötä tehdään aina asiakkaan hyväksi ja siinä hyödynnetään monipuolista asiantuntijuutta. Eri toimialoilla, kuten aikuissosiaalityössä ja päihdetyössä, tehdään usein työtä tiimeittäin. Tiimin jäsenet vastaavat eri työtehtävistä, joiden asiantuntijoita he ovat. Tiimityöskentely voi olla myös moniammatillista. Sosiaalityöntekijä ja -terapeutti voivat konsultoida tiiminsä ulkopuolista työntekijää, kuten esimerkiksi päihdesairaanhoitajaa tai lääkäriä, etsiessään apua ongelmallisesti pelaavalle asiakkaalleen. Myös ulkopuolinen työntekijä, kuten velkaneuvoja tai diakoniatyöntekijä, voi ottaa yhteyden sosiaalityön ammattilaiseen saadakseen apua asiakkaalleen.

"Meillä saa sosiaalityöntekijä itse muokata sitä rooliansa. Itse tykkään tehdä tietynlaisia rajauksia, että teen sellaisia asioita, joita perinteisesti ajatellaan sosiaalityöntekijän tekevän. Olisin voinut lähteä hoidollisemmalle linjalle, mutta tämähän on moniammatillinen työryhmä, niin varsinkin kuntoutusympyröistä sain sen kokemuksen, että se toimii hirveän hyvin, kun jokaisella on selkeä rooli ja vähän rajaa siinä työn ja ammatin kuvassa. Ettei tehdä päälekkäin ja ristiin. Tehdään omasta kantista sitä työtä ja sitten on ikään kuin se, että asiakas on se kohde ja sitten kaikki pääty asiakkaan hyväksi, kun jokainen toimii omalla tontillaan." (RS7)

Haastatteluaineiston perusteella sosiaali- ja päihdetyöntekijöiden tietoisuus ongelmapelaajille ja heidän läheisilleen tarkoitetuista tuki- ja hoitopalveluista ja kyseisten palveluiden saatavuus paikkakunnalla vaikuttivat siihen, kuinka haastateltavat konsultoivat palveluista vastaavia työntekijöitä tai tekivät yhteistyötä heidän kanssaan. Peluuri, joka tarjoaa puhelimitse ja sähköisesti palvelujaan, oli tutuin sosiaalityöntekijöille. Asiakkaille haettiin apua myös päihdepalveluista, joko avohoidosta tai kuntoutuksesta. Asiakkaan ympärille saatettiin myös rakentaa moniammatillinen tukiverkosto, jossa hyödynnettiin muita palveluja. Lisäksi osa haastateltavista oli erilaisissa työhönsä liittyvissä verkostoissa mukana.

"Siinä hoidon tarpeen arvioinnin aikana, kun asiakas tuli meille työpaikalta hoitoon ohjattuna, tuli sitten esille, että hän pelaa jatkuvasti raha- ja nettipelejä. Sitä pelaamista oli todella paljon. Lähdin pohtimaan, että mikä olisi järkevä etenemistapa ja otin yhteyttä Peliklinikkaan. Sovittiin sitten yhteistapaaminen. Itse otin yhteyttä, koska asiakkaan oli hirveän vaikea saada tehtyä asioita tai hoidettua ylipäätään mitään." (RS9)

Muutamat haastateltavat auttoivat asiakkaitaan vetämällä ohjattuja vertaistuki- ja kuntoutusryhmiä. Jotkut olivat käyneet kouluttamassa muita ammattilaisia ja luennoimassa ongelmapelaajien vertaisryhmässä. Läheiset saattoivat olla mukana (asiakkaan toiveesta) ainakin kerran verkostokokouksissa, joita järjestettiin päihdepalveluissa.

"Teen yhteistyötä [vertaisryhmän] vetäjän kanssa, ja me vierailemme toistemme ryhmissä ja mainostetaan [omaa ryhmätoimintaamme] toistemme ryhmissä. Siitä ei ole haittaa, vaikka ihmiset käyvät monissa ryhmissä. (...) Myös [toiset] ovat pyytäneet minua puhumaan sinne [vertaisryhmään], 
joten olen menossa sinnekin sitten esitelmöimään. Tai en minä mitään esitelmöi, mutta kerron siitä mitä itse olen työssäni nähnyt, ja millä tavalla yritän hoitaa ja auttaa näitä ihmisiä.” (RS23)

Merja Laitinen $(2018,157)$ nostaa esiin Anna Metterin jaottelun,jonka mukaan yhteistyössä asiantuntijuutta voidaan tarkastella "multiprofessionaalisuuden" ja "interprofessionaalisuuden" näkökulmista. Jos ensimmäisessä tapauksessa ammattiryhmät säilyttävät "perinteiset roolit ja hierarkiat", toisessa tapauksessa eri ammattien välille muodostuu "yhteistä tavoitteellista toimintaa, jossa syntyy uudenlaisia toimintamalleja ja osaamista". Tällöin eri ammattien asiantuntijatyötä vahvistetaan jakamalla tietoa ja asiantuntijuutta. (Laitinen ym. 2018, 157.) Aineistossa on esimerkkejä sekä multiprofessionaalisuudesta että interprofessionaalisuudesta. Haastateltavat ovat valmiita hakemaan tietoa ja asiantuntijuutta oman työpaikkansa ulkopuolelta auttaakseen asiakasta, mutta myös verkostoitumaan saadakseen tietoa ja jakamalla omaa osaamistaan ongelmapelaamisesta.

\section{Pohdinta}

Suomessa ja kansainvälisesti sosiaalialan ammattilaisten työskentely ongelmapelaajien kanssa on kiinnostanut tutkijoita yllättävän vähän. Tässä artikkelissa olemme halunneet nostaa kyseisten ammattilaisten asiantuntijuutta esiin sen sijaan, että keskittyisimme pelkästään osaamiseen kartoittamiseen. Tarkastelimme asiantuntijuutta ilmiöiden käsittelytapojen, tiedon hankkimisen, auttamismenettelyjen ja asiakkaiden kohtaamisen kautta. Keskityimme kuuntelemaan työntekijöiden kerrontaa, jossa vuorottelivat työtehtävien asettamat näkökulmat, omat onnistumiset ja haasteet sekä tietenkin haavoittuvassa asemassa olevien asiakkaiden elämäntarinat.

Tavoitteenamme oli haastatella sosiaalityöntekijöitä. Emme päässeet tavoitteeseemme, sillä aina emme tavoittaneet yliopistotutkinnon omaavia työntekijöitä. Tätä voi toki pitää rajoitteena tutkimustulosten kannalta. Sosiaalityöntekijän, -ohjaajan ja -terapeutin asiantuntijuus ei tällöin perustuisi samanlaiseen osaamiseen, koska asiantuntijuuden suhde tieteelliseen tietoon ja tiedon hyödyntämiseen työssä on erilainen (vrt. Raunio 2011, 118). Päätimme kuitenkin tutkia asiantuntijuutta koko haastatteluaineiston avulla, sillä halusimme mahdollisimman kattavan kuvan sosiaalialan toimialoista, joissa saatetaan kohdata ongelmallisesti pelaavia asiakkaita, ja ammattilaisten työtehtävistä. Sosiaalityöntekijöiden asiantuntijuuden määritelmä voi olla kiistanalainen kysymys (Fook ym. 1997, 404). Tutkimuksemme keskiössä olivat kuitenkin ongelmapelaajat, eikä niinkään asiantuntijuuden tason vertailu koulutuksen mukaisesti.

Sosiaalityöllä "on erityinen eettinen velvollisuus hyvinvointityönä" ja sen tehtävänä on "tunnistaa ja tuoda näkyväksi ajankohtaisia yhteiskunnallisia prosesseja, jotka uhkaavat yksilöiden, perheiden ja yhteisöjen hyvinvointia" (Pehkonen \& Väänänen-Formin 2011, 7). Haastatteluissa korostui työntekijöiden halu auttaa, vaikka aina paikallisia palveluja ongelmapelaajille ei ollut tarjota. Sosiaalityössä etiikka yhdistyy arvokysymyksiin, jolloin on tärkeää 
pohtia työskentelyä palvelujen käyttäjien kanssa, sosiaalityön roolia yhteiskunnassa ja uusia nousevia ammatillisia arvoja (esimerkiksi palvelujen käyttäjien voimaannuttaminen) (Shardlow 1998, 25). Työ ongelmapelaajien kanssa saattoi olla haastavaa, koska monilla oli samanaikaisia ongelmia tai ongelmat seurasivat toisiaan. Haastatteluaineiston perusteella voi päätellä, että koulutusta voi lisätä erityisesti toiminnallisten riippuvuuksien saralla, jotta asiakkaita ei kohdeltaisi poikkeuksina normaalissa arkityössä.

Aineistosta löytyi merkkejä valta-asetelmista. Vallan kysymys voi liittyä sosiaalialan työntekijöiden haluun saada aikaan muutosta asiakkaiden elämässä, mutta työntekijöiden itsensä ehdoilla. Tällöin asiantuntijuus tulee vinoutuneesti käyttöön: pahimmillaan asiakkaiden ja työntekijöiden arvomaailmat törmäävät toisiinsa ja vuorovaikutusta ei synny. Yksi vallankäytön muodoista voi olla myös se, että sosiaalialan ammattilaiset vähättelevät asiakkaittensa kokemuksia tai vastuullistavat asiakkaitaan ongelmistaan sen sijaan, että he miettisivät rakenteellista eriarvoisuutta yhteiskunnassa (Banks 2011, 15). Aineistossa saatettiin tuoda esille myönteisesti asiakkaiden oma halu tehdä ongelmalle jotain, mutta samalla saatettiin kritisoida asiakkaiden tapaa kieltäytyä ongelman käsittelystä tai työntekijän kuuntelusta. Ongelmapelaajat menettävät monella tapaa elämänhallinnan ja vallan päättää asioistaan. Näin ollen olisi erityisen tärkeää, että sosiaalialalla kiinnitettäisiin huomiota heidän voimaannuttamiseensa (vrt. Shardlow 1998, 31).

\section{YHTEENVETO}

Tässä tutkimuksessa on käsitelty asiantuntijuuden muodostumista sosiaalialalla, kun asiakkaana on ongelmallisesti rahapelejä pelaava henkilö. Asiantuntijuus alkaa useimmiten yhteiskunnallisen ilmiön hahmottamisesta, jolla viitataan asiakkaiden kertomusten sekä omien kokemusten ja havaintojen hyödyntämiseen ilmiön ymmärryksessä. Ennen toimeentuloasioiden siirtoa Kelaan sosiaalityöntekijät ja -ohjaajat saattoivat ottaa rahapelaamisen puheeksi suhteellisen luontevasti osana tiliotteiden läpikäyntiä. Joillekin asiakkaille rahapelaamisesta puhuminen oli vaikeaa, sillä siihen liittyy paljon häpeän, syyllisyyden ja leimaantumisen pelon tunteita. Aineistossa käytiin myös keskustelua siitä, tulisiko rahapelaaminen ottaa puheeksi, ja kuinka työntekijän tulisi toimia jos tämä ei omaa riittävää osaamista riippuvuuksien saralla. Asiantuntijuus ei ole kuitenkaan pelkästään yhden työntekijän varassa, vaan haastateltavat tekivät myös yhteistyötä kollegoittensa ja muiden ammattilaisten kanssa tukeakseen ja auttaakseen asiakkaitaan. Yhteistyössä hyödynnettiin monipuolista asiantuntijuutta ja moniammatillista osaamista. Ongelmapelaajille tarkoitetuista erityispalveluista tutuin oli $\mathrm{Pe}-$ luuri, mutta asiakkaille haettiin apua myös esimerkiksi päihdepalveluista.

Haastateltavien asiantuntijuudessa yhdistyvät sekä teoria (episteme) että käytäntö (techne) (Flyvberg 2001, 2-4). Asiantuntijuus perustuu tieteelliseen tietoon, joka on yleistettävissä olevaa, universaalia, tarkkaa ja joka auttaa työntekijää päättelemään asioita yleisestä erityiseen. Toisaalta se perustuu käytännölliseen tietoon, jonka voi ymmärtää 
tässä palvelujen tarjoamiseksi, lainsäädännön tuntemiseksi ja asiakkaan oikeuksien valvomiseksi. (Fook 2016, 51.) Tieto tai "käytännöllinen viisaus" (phronesis) voi olla myös hyvän nimissä toimimista tietyssä kontekstissa: toisin sanoen sosiaalityössä tämä merkitsisi tiedon käyttöä perustellusti ja arvoihin perustuen suhteessa työtehtävän asettamaan kontekstiin (Fook 2016, 51; Flyvberg 2001,2). Ongelmallisesti pelaavien asiakkaiden puolesta on toivottavaa, että sosiaalialalla teoreettinen osaaminen ja käytännön asiantuntijuus yhdistyisivät sosiaalityön eettisiin perusteisiin ja jaettuihin arvoihin, jotta asiakkaat tulisivat kuulluiksi ja autetuiksi ja heillä olisi mahdollisuus voimaantua jälleen kokonaisvaltaisiksi yksilöiksi.

\section{VIITE}

1 Haastateltavien rekrytoinnin ja haastattelut toteutti VTM Eija Pietilä, joka toimi vuonna 2016 tutkimusassistenttina Rahapeliongelmat sosiaalityössä -tutkimushankkeessa.

\section{Kirjallisuus}

Banks, Sarah (2011) Ethics in an Age of Austerity: Social Work and the Evolving New Public Management. Journal of Social Intervention: Theory and Practice 20 (29), 5-23. https://doi.org/10.18352/ jsi. 260

Castrén, Sari \& Alho, Hannu \& Salonen, Anne (2016) Rahapeliongelma sosiaalija terveydenhuollossa - ammattilaisten näkemyksiä.Yhteiskuntapolitiikka 81 (4), 418-428.

Egerer, Michael (2013) Problem drinking, gambling and eating - three problems, one understanding? A qualitative comparison between French and Finnish social workers. Nordic Studies on Alcohol and Drugs 30 (1-2), 67-86.
Elo, Satu \& Kyngäs, Helvi (2007) The qualitative content analysis process. Journal of Advanced Nursing 62 (1), 107-115. https://doi.org/10.1111/j.13652648.2007.04569.x

Engel, Rafael J. \& Bechtold, Jody \& Kim, Yoonmi \& Mulvaney, Elizabeth (2012) Beating the Odds: Preparing Graduates to Address Gambling-Related Problems. Journal of Social Work 48 (2), 321-335. https://doi.org/10.5175/ JSWE.2012.201000128

Eräsaari, Leena (1995) Kohtaamisia byrokraattisilla näyttämöillä. Helsinki: Gaudeamus.

Eräsaari, Risto (2002a) Kuinka turvaton on riittävän turvallinen? Polemia-sarjan julkaisu 46. Vammala: Kunnallisalan kehittämissäätiö.

Eräsaari, Risto (2002b) Avoimen asiantuntijuuden analytiikka. Teoksessa Ilkka Pirttilä \& Susan Eriksson (toim.) Asiantuntijoiden areenat. Jyväskylä: Kopijyvä Oy, 21-38.

Eskola, Jari \& Suoranta, Juha (2000) Johdatus laadulliseen tutkimukseen. Tampere: Vastapaino.

Fook, Jan (2016) Social Work: A Critical Approach to Practice. $3^{\text {rd }}$ edition. London, Thousand Oaks, New Delhi \& Singapore: Sage.

Fook, Jan \& Ryan, Martin \& Hawkins, Linette (1997) Towards a Theory of Social Work Expertise. British Journal of Social Work 27, 399-417. https:// doi.org/10.1093/oxfordjournals.bjsw. a011220

Flyvberg, Bent (2001) Making Social Science Matter. Why social science inquiry fails and how it can succeed again. Cambridge: Cambridge University Press. https://doi.org/10.1017/ CBO9780511810503

Gaiswinkler, Wolfgang \& Roessler, Marianne (2009) Using the expertise of knowing and the expertise of not-knowing to support processes of empowerment in social work practice. Journal of Social Work Practice 23 (2), 215-227. https:// doi.org/10.1080/02650530902923874

Gilbert, Tony \& Powell, Jason L. (2010) Power and Social Work in the United Kingdom. A Foucaldian Excursion. Journal of Social Work 10 (1), 3-22. https:// 
doi.org/10.1177/1468017309347237

Heinonen, Jari (2012) Miesten kokemuksia köyhyydestä ja asiakkuudesta. Teoksessa Katja Forssén \& Irene Roivainen \& Satu Ylinen \& Jari Heinonen (toim.) Kohtaako sosiaalityö köyhyyden? Kuopio: UNIpress, 197-222.

Heiskanen, Maria \& Egerer, Michael (2018) The conceptualization of problem gambling in social services: email interviews with Finnish social services directors. Nordic Social Work Research 9 (1), 29-41. https://doi.org/10.1080/215685 7X.2018.1426625

Huotari, Kari (2009) Sattumanvaraisuuden koordinointiin. Ongelmapelaajien tukija hoitopalvelut sekä hoitopalvelujärjestelmän kehittäminen. Helsinki: Terveyden ja hyvinvoinnin laitos.

Hänninen, Sakari (2006) Huono-osaisuuden mieli. Teoksessa Sakari Hänninen \& Jouko Karjalainen \& Tuukka Lahti (toim.) Toinen tieto. Kirjoituksia huonoosaisuuden tunnistamisesta. Helsinki: Sosiaali- ja terveysalan tutkimus- ja kehittämiskeskus, 94-117.

Juhila, Kirsi (2006) Sosiaalityöntekijöinä ja asiakkaina. Sosiaalityön yhteiskunnalliset tehtävät ja paikat. Tampere:Vastapaino.

Juhila, Kirsi (2018) Aika, paikka ja sosiaalityö. Tampere:Vastapaino.

Järvinen-Tassopoulos, Johanna (2011) Pelaavien naisten nettikeskustelujen käytön ja analyysin eettiset haasteet. Teoksessa Sami Lakomäki \& Pauliina Latvala \& Kirsi Laurén (toim.) Tekstien rajoilla. Monitieteisiä näkökulmia kirjoitettuihin aineistoihin. Helsinki: Suomalaisen Kirjallisuuden Seura, 202-229.

Kivipelto, Minna \& Saikkonen, Paula (2013) Tiedon tuotanto ja vaikuttavuustieto sosiaalityössä. Yhteiskuntapolitiikka 78 (3), 313-321.

Konttinen, Esa (1997) Professionaalinen asiantuntijatyö ja sen haasteet myöhäismodernissa. Teoksessa Juhani Kirjonen \& Pirkko Remes \& Anneli Eteläpelto (toim.) Muuttuva asiantuntijuus. Koulutuksen tutkimuslaitos. Jyväskylä: Jyväskylän yliopisto, 48-61.

Kuula, Arja (2006) Yksityisyyden suoja tutkimuksessa. Teoksessa Jaana Hallamaa \&Veikko Launis \& Salla Lötjönen \& Irma Sorvali (toim.) Etiikkaa ihmistie- teille. Tietolipas 2011. Helsinki: Suomalaisen Kirjallisuuden Seura, 124-140.

Laitinen, Merja \& Kemppainen, Tarja \& Lakkala, Suvi \& Kauppi, Arto \& Veikanmaa, Sari \& Välimaa, Miia \& Turunen, Tuija (2018) Sosiaalityön interprofessionaalinen asiantuntijuus - tapausesimerkkinä koulun sosiaalityö. Teoksessa Tarja Juvonen \& Jari Lindh \& Anneli Pohjola \& Marjo Romakkaniemi (toim.) Sosiaalityön muuttuva asiantuntijuus. Helsinki: UNIpress, 154-181.

Leppälahti, Raija (2014) Asiakas- ja perhekeskeinen työkäytäntö perusterveydenhuollossa.Teoksessa Anna Metteri \& Heli Valokivi \& Satu Ylinen (toim.) Terveys ja sosiaalityö. Jyväskylä: PS-Kustannus, 44-51.

Lindh, Jari \& Pohjola, Anneli \& Juvonen, Tarja \& Romakkaniemi, Marjo (2018) Johdatus sosiaalityön asiantuntijuuden muutokseen. Teoksessa Tarja Juvonen \& Jari Lindh \& Anneli Pohjola \& Marjo Romakkaniemi (toim.) Sosiaalityön muuttuva asiantuntijuus. Helsinki: UNIpress, 9-15.

Manthorpe, Jill \& Norrie, Caroline \& Bramley, Stephanie (2018) GamblingRelated Harms and Social Work Practice: Findings from a Scoping Review. Practice: Social Work in Action 30 (3), 187-202. https://doi.org/10.1080/0950 3153.2017.1404563

Momper, Sandra L. (2014) Implications of American Indian Gambling for Social Work Research and Practice. Social Work 55 (2), 139-146. https://doi. $\mathrm{org} / 10.1093 / \mathrm{sw} / 55.2 .139$

Mutka, Ulla (1998) Sosiaalityön neljäs käänne. SoPhi 27. Jyväskylä: Jyväskylän yliopisto.

Mönkkönen, Kaarina (2018) Vuorovaikutus asiakastyössä. Asiakkaan kohtaaminen sosiaali- ja terveysalalla. Helsinki: Gaudeamus.

Pehkonen, Aini \& Väänänen-Formin, Marja (2011) Arvojen ja etiikan dilemma sosiaalityössä. Teoksessa Aini Pehkonen \& Marja Väänänen-Formin (toim.) Sosiaalityön arvot ja etiikka. Sosiaalityön tutkimuksen seuran vuosikirja 2011. Jyväskylä: PS-Kustannus, 7-10.

Pirttilä, Ilkka (2002) Mistä asiantuntemuksen sosiologiassa on kyse? Teoksessa Ilkka 
Pirttilä \& Susan Eriksson (toim.) Asiantuntijoiden areenat. Jyväskylä: Kopijyvä Oy, 11-19.

Pohjola, Anneli (2007) Merkintöjä sosiaalityön asiantuntijuudesta. Teoksessa Kerttu Vesterinen (toim.) Kiitos kysymyksestä. Pohjois-Suomen sosiaalialan osaamiskeskuksen julkaisusarja 27. Rovaniemi: Pohjois-Suomen sosiaalialan osaamiskeskus, 6-18.

Pohjola, Anneli (2011) Rakenteellisen sosiaalityön aika. Teoksessa Anneli Pohjola \& Riitta Särkelä (toim.) Sosiaalisesti kestävä kehitys. Helsinki: Sosiaali- ja terveysturvan keskusliitto ry, 207-224.

Raiski, Tuula-Leena (2011) Osaamistarve rahapelien ehkäisyssä ja hoidossa. Helsinki: Terveyden ja hyvinvoinnin laitos.

Raitakari, Suvi (2002) Sosiaalityön marginaalistatus. Asiakkuus ja asiantuntijuus modernin ja postmodernin tulkintakehyksessä. Teoksessa Kirsi Juhila \& Hannele Forsberg \& Irene Roivainen (toim.) Marginaalit ja sosiaalityö. Jyväskylä: Kopijyvä $\mathrm{Oy}, 44-62$.

Raunio, Kyösti (2011) Sosiaalityön etiikka näyttöön perustuvan käytännön haasteena. Teoksessa Aini Pehkonen \& Marja Vänänen-Formin (toim.) Sosiaalityön arvot ja etiikka. Sosiaalityön tutkimuksen seuran vuosikirja. Jyväskylä: PS-Kustannus, 117-138.

Renko, Elina (2018) Pyhä toimijuus. Miten sosiaalityön asiakkaat ja ammattilaiset asennoituvat alkoholinkäytön puheeksiottoon ja käyttöön liittyvään neuvontaan? Helsingin yliopisto: Sosiaalitieteiden laitos.
Rogers, Jim (2013) Problem Gambling: A Suitable Case for Social Work? Practice: Social Work in Action 25 (1), 41-60. https://doi.org/10.1080/09503153.201 3.775234

Saaristo, Kimmo (2000) Avoin asiantuntijuus. Ympäristökysymys ja monimuotoinen ekspertiisi. Jyväskylä: Nykykulttuurin tutkimuskeskus.

Salonen, Anne \& Hagfors, Heli \& Lind, Kalle \& Kontto, Jukka (2020) Rahapelaaminen ja peliongelmat - Suomalaisten rahapelaaminen 2019. Helsinki: Terveyden ja hyvinvoinnin laitos.

Shardlow, Steven (1998) Values, ethics and social work. Teoksessa Robert Adams \& Lena Dominelli \& Malcolm Payne (toim.) Social work: Themes, issues and critical debates. Basingstoke \& London: Macmillan Press Ltd, 23-33. https://doi. org/10.1007/978-1-349-14400-6_2

Sipilä, Anita (2011) Sosiaalityön asiantuntijuuden ulottuvuudet - Tiedot, taidot ja etiikka työntekijöiden näkökulmasta kunnallisessa sosiaalityössä. Kuopio: ItäSuomen yliopisto.

Tuomi, Jouni \& Sarajärvi, Anneli (2002) Laadullinen tutkimus ja sisällönanalyysi. 1.-3. painos. Helsinki: Kustannusosakeyhtiö Tammi.

Webb, Stephen A. (2000) The Politics of Social Work: Power and Subjectivity. Critical Social Work 1 (2), 1-5. 